\title{
Opinion
}

\section{Health Care Reform - Involving Our Physician Leaders}

David S. Kloth, MD

In 2010, Congress passed sweeping health care reform legislation, The Patient Protection and Affordable Care Act, which was signed into law by President Obama (1-4). This legislation provides major changes to our health care system which we all hope results in a more efficient, less expensive, more widely accessible health care delivery system. While physicians, patients, insurance carriers, and the government all agree that changes were required, there still remain some differences in how to accomplish this agenda, and about the merits of various aspects of this major health care renovation.

Of primary importance to physicians is that their patients have access to high quality, safe, efficient, state-of-the-art health care. The costs of this care must be balanced against its effectiveness. In this regard, health care reform legislation provides structure for comparative effectiveness research to help determine which treatments are best for our patients. Unfortunately, it will be years before much of this research is available and before comparative effectiveness research can provide specific guidelines or coverage policies which will help control health care costs. Given the limitations of both money and time, there are many treatments which will need to rely on the evidence which exists today 5-8).

It is well known that there is a significant amount of waste in the U.S. health care system and it is paramount that this decrease given the amount of money this is estimated to cost. Unfortunately, the physician leaders of our national medical societies have little control over what individual physicians do in this country and so cannot at this stage help to control these costs. Guidelines developed and released by professional medical organizations are non-binding and societies lack the authority to require that physicians follow them or to enforce them. Today it is estimated that we waste upwards of $\$ 800$ billion/year on abuse, fraud, unnecessary health care, and administrative costs with medical mistakes comprising another \$50-100 billion/year. While these are just estimates, no one questions that there are significant dollars being spent on health care that are both unnecessary and wasteful (1-5).

The physician leaders of national medical societies have intimate knowledge of many areas of waste, abuse, and fraud, but unfortunately have no ability to specifically control this area of health care expenditure. While comparative effectiveness research (CER) may solve some of these problems, it will not solve all, and may not be able to respond quickly enough to changes in medicine to provide the cost containment that is hoped. Just as importantly, both physicians and patients (the American people) are concerned that this will lead to rationing of health care in an inappropriate way. In addition, CER will not be available for a number of years, and in the interim we will continue to waste significant health care dollars (5-8). At this time in America, given our economic conditions, the escalating cost of health care, and skyrocketing insurance premiums, we need to find ways to control this more rapidly.

We have seen attempts by government agencies to review health care policies and technology; sometimes these are fruitful and provide meaningful coverage policies, but all too often these result in restriction of care to the point of rationing. We have seen

From: Connecticut Pain Care, Danbury, CT Dr. Kloth is Medical Director, Connecticut Pain Care, Danbury, CT. He is also a Director at Large and Past President of the American Society of Interventional Pain Physicians E-mail: dkmd@ctpaincare.com

Disclaimer: There was no external funding in the preparation of this manuscript. Conflict of interest: None. 
this with all insurance carriers, both public and private, with some of these non-coverage decisions preventing access to safer, less invasive, and more cost-effective health care.

As an example, the state of Washington has recently provided specific recommendations from their Health Technology Assessment (HTA) Committee on a variety of medical treatments (9-12). have closely followed this process through several national organizations, and have found that their decisions are far from transparent. From the decision process on how treatments are to be selected for review through the final coverage decision, the HTA provides no comment or rationale as to how these are made.In addition, their decisions are flawed, and seem to be biased, based on their approach to the review process. Good literature is often ignored or discounted in favor of literature of weaker quality but which supports the position of the committee. Expert opinion is discounted or purely ignored, instead relying on the opinions of committee experts, who lack both training and expertise about the treatments under review. The net result is that this has led to incorrect and/or inadequate coverage policies for patients in the state of Washington and that patients will not have access to the care that they need. I do not believe that this is the intention of health care reform in this country. Unfortunately, these guidelines or recommendations are usually developed by physicians without expertise in the field of study and therefore it is beyond their scope of practice. In a malpractice court those physicians would not even be allowed to take the stand; the judge would disqualify them as non-experts, yet these doctors are allowed to decide treatment on complex therapies for which they have no basis of knowledge. The same has occurred with guidelines put forth by groups such as ACOEM, where a lack of expert opinion has been shown, and where conflicts of interest were not disclosed (13-18).

The Washington State HTA Committee's recommendations and coverage policies affect government employees, Medicaid patients, and workers' compensation patients. At this point these groups of patients will no longer be able to receive the same quality and level of care as someone working for a private employer who is the beneficiary of a private independent insurance carrier. The same treatments for which the HTA has recommended against coverage are covered treatments under Medicare. This creates 2 separate levels of carenot the intention of health care reform. Currently there is legislation being considered in Washington state to expand this to all private carriers within the state (HB 1311).

The decisions that the HTA Committee has made will result in patients' inability to receive medically indicated and appropriate pain treatment (I can only speak specifically about pain treatments, my area of expertise, but they have reportedly made questionable coverage decisions in other areas of medicine). They have already provided negative coverage decisions for some of the most important therapies that exist for chronic pain conditions; and now are looking to deny coverage for a vast array of other pain treatments. I would note all of the therapies currently under review are again covered by Medicare and all major insurance carriers across the country. In fact, these treatments have been shown through many studies to provide good pain relief and to be cost effective as they limit the need for alternative, more expensive treatments, such as further spinal surgery or chronic medications. However, a biased use of the literature is again being used to create a basis for their decision and it would again appear that all expert input is being ignored. To complicate matters even further, the state of Washington has passed a law which will severely restrict patient access to physicians for the provision of chronic pain medications. The ultimate result of this is that patients in the state of Washington will often be forced to live in chronic pain and not be able to receive adequate treatment.

While ASIPP, my national society, supports the judicious use of evidence-based medicine (EBM), this cannot be used in a vacuum and must be combined with clinical judgment to arrive at reasonable coverage policies (19-25). Many patients don't fit into the strict criteria set forth by studies leaving what to do for treatment more open to interpretation. This is exactly where clinical judgment becomes so important. Much of the literature is complex, and the ability to understand and interpret it properly requires some base knowledge of the field in question, especially when trying to understand which studies are good and which are flawed. This absolutely requires the involvement of physician experts within the field of study.

The HTA Committee is currently looking at a number of other pain treatments and we are very fearful that this will again result in further negative coverage policies. Multiple national medical societies and leading experts within the field have provided scientific evidence in support of these pain treatments. The HTA Committee, despite having no member with specific training in this field of medicine, has already provided 
coverage policies on several therapies that are in stark disagreement to the recommendations provided by national societies and leading physician experts. All contrary comments were seemingly ignored, dismissed, or discounted. This is not the kind of healthcare reform that President Obama spoke about, that Congress voted for, or that the American people want. These decisions by the HTA Committee, as it relates to pain treatment, in Washington state will lead to government-sanctioned torture (26). As an aside, I would note that interestingly, physician-assisted suicide is a covered service in Washington state.

As a physician leader who has been involved with multiple national medical societies, I have gained a unique perspective on many of these health care issues. I have spent significant time studying these matters and have been involved in the writing of various guidelines over the years. I have worked with not only the Centers for Medicare and Medicaid Services, but also local Medicare carriers, to draft coverage policies for various therapies. I have worked with the Drug Enforcement Agency, and most recently have reached out to the Office of National Drug Control Policy to try and assist with their work regarding rampant prescription drug abuse in this country. I would note that all of these are non-paid positions; they are done in an altruistic spirit to try to improve the health care system that we currently exist within. There are many other leaders such as I, who are and have been willing to give of their time to improve the health care delivery system.

We all agree that it is imperative that we gain control of some of the waste and abuse that is occurring in this country. Not only does it waste health care dollars, unfortunately many of these treatments have significant associated risks, which can lead to increasing health care costs due to complications. As physician leaders we feel it is imperative that we weigh in on this issue and try to assist the federal government in bringing these matters under control sooner than later. We cannot wait 5 years for CER to begin providing information that will help us. As I pointed out earlier, it will be many years longer than that before CER can get to all of the areas of medicine. In addition, CER will not address many of the problems that exist today and may be too slow to respond to the rapid changes that occur in medicine. There is widespread agreement that waste and abuse must be addressed and the sooner this occurs the better; the economic health of our health care delivery system and the safety of our citizens depend on it.
I am proposing to the federal government that they work in concert with physician leaders, specifically through their national societies, to develop evidencebased guidelines for the delivery of health care. This should occur in every single area of medicine and these guidelines should be drafted by the leaders of our national medical societies to ensure continued proper access while controlling fraud, waste, and abuse. We also must address who is performing the various treatments and make sure that the proper level of training has been achieved by those providers to limit the risks, ensure appropriate medical decision making, and improve public safety. The government will need to work with us, listen, and help us to implement many of the changes that will be necessary. Again, as leaders of national medical societies, we are well aware of the problems that are occurring; we see it every day, but unfortunately our hands are tied in controlling these issues under the current system.

Working with physicians to address these issues will help demonstrate to both doctors and the American people the government's intentions of ensuring appropriate access to high quality and safe health care in the United States. In the field of pain management, the specialty I currently practice, we firmly believe that we can develop guidelines that will result in a $20-30 \%$ savings in overall health care expenditures within our field. I am absolutely sure that every area of medicine can come up with similar guidelines to help control some of the poor quality care that is currently being delivered in the United States. This can be done fast, within one year, and these guidelines or coverage policies can serve as templates for the federal government to review during their CER process. It will also help the Comparative Effectiveness Research Committee to determine areas which require further study to improve evidence and ensure that American health care dollars are being well spent.

Health care coverage policies written by national societies and physician leaders, our experts, would be accepted by the American people much sooner than coverage policies dictated by a governmental agency. This will address many of the fears and concerns of the American people as it relates to rationing. This approach would not eliminate anything that the government is currently looking at, but would speed up the process of developing guidelines and coverage policies, which will help control health care costs sooner. At a minimum it will give the CER programs a starting point from which to begin, and this should theoretically assist 
them in their work. Hopefully this approach could serve as the template for future projects between physicians and government agencies. It will most importantly ensure that patients have access to the therapies that physicians believe to be important today.

It is my belief that national medical societies would do this work at no charge as it will benefit their members, patients, and the health care delivery system as a whole. It will enable them to ensure that patients can have access to the therapies that they believe to be important. These guidelines to ensure proper access and continued access must address overutilization, underutilization, and improper utilization of health care and more specifically health care technology, which continues to advance at a rapid rate in the United States. It will place the burden on national medical societies to find ways to control expenses within their own areas of expertise, to make the difficult decisions as to who should get what treatment, with a clear directive that wasteful spending and unnecessary treatment must come to an end. If they fail they will only be able to blame themselves.

Because of the clear potential for conflict of interest, it is my recommendation that any physician who is involved in this work for their specialty society drafting guidelines and coverage policies, must have absolutely no consulting ties to industry. This will help address many of the concerns raised by Congress over the last several years.

I believe that the physicians and the government working together can create a more efficient and cost effective health care system. The monies that can be saved through this process can be used to cover the millions of Americans who will now have insurance coverage available to them through the expansion of Medicaid and the buying cooperatives which will exist in the next several years.

I therefore respectfully request the government take a chance and work with physicians. We are smart, we have spent many years training to do our work, we see and understand the problems, and most importantly, we can help you to fix them quickly. We can create guidelines and coverage policies that will help you determine what health care should be paid for, how it should be paid for, and help address much of the waste that must be eliminated. It will be up to the government to enforce these coverage policies, as medical societies do not have the statutory authority to ensure their enforcement.

In conclusion, I propose to the federal government that they work with national medical societies and experts to develop guidelines and coverage policies to help direct our health care system to develop efficient, cost-effective coverage policies to improve public safety

\section{References}

1. Manchikanti L, Hirsch JA. Obama health care for all Americans: Practical implications. Pain Physician 2009; 12:289. 304 .

2. Manchikanti L, Caraway DL, Parr AT, Fellows B, Hirsch JA. Patient Protection and Affordable Care Act of 2010: Reforming health care reform for the new decade. Pain Physician 2011; 14:E35E67.

3. Public Law No: 111-148: H.R. 3590. Patient Protection and Affordable Care Act. March 23, 2010.

4. Bredesen P. Fresh Medicine: How to Fix Reform and Build a Sustainable Health Care System. Atlantic Monthly Press, New York, 2010.

5. Manchikanti L, Falco FJE, Boswell MV, Hirsch JA. Facts, fallacies, and politics of comparative effectiveness research: Part 1. Basic considerations. Pain Physician 2010; 13:E23-E54.
6. Manchikanti L, Falco FJE, Boswell MV, Hirsch JA. Facts, fallacies, and politics of comparative effectiveness research: Part 2. Implications for interventional pain management. Pain Physician 2010; 13:E55-E79.

7. Evans H. Comparative effectiveness in health care reform: Lessons from abroad. Backgrounder No. 2239; February 4, 2009.

8. Sackett DL, Rosenberg WM, Gray JA, Haynes RB, Richardson WS. Evidence based medicine: What it is and what it isn't. BMJ 1996; 312:71-72.

9. Turner JA, Hollingworth W, Comstock BA, Deyo RA. Spinal Cord Stimulators (SCS) for Injured Workers with Chronic Pain after Lumbar Surgery - A Prospective Study to Describe Costs, and Patient Outcomes: Final Report . Washington State Department of Labor and Industries, Office of Medical Director;
September 30, 2008.

www.Ini.wa.gov/ClaimsIns/Files/ OMD/FinalReportSCS.pdf - 2010-08-26

10. Hashimoto R, Raich A, Ecker E, Henrikson NB, Wallace L, Dettori JR, Chou R. Health Technology Assessment, Washington State Health Care Authority. Spinal Injections. Spectrum Research, Inc., December 14, 2010.

www.hta.hca.wa.gov/documents/spinal_injection_final_report.pdf

11. Hashimoto R, Dettori JR, Henrikson NB, Kercher L. Chou R. Health Technology Assessment, Washington State Health Care Authority. Spinal Cord Stimluation. Spectrum Research, Inc., July 23, 2010.

www.hta.hca.wa.gov/documents/scs_ 072310_report_final.pdf

12. Noble M, Treadwell J, Schoelles K, Sun F. Health Technology Assessment, Washington State Health Care Author- 
ity. Implantable Infusion Pumps for Chronic Noncancer Pain. ECRI Institue, July 18, 2008.

www.hta.hca.wa.gov/documents/implantable_infusion_pumps_final.pdf

13. Manchikanti L, Gupta S, Benyamin R, Munglani R, Datta S, Hirsch JA, Ward SP. In response from Manchikanti et al. Pain Physician 2011; 14:E73-E80.

14. Manchikanti L, Datta S, Derby R, Wolver LR, Benyamin RM, Hirsch JA. A Critical Review of the American Pain Society clinical practice guidelines for interventional techniques: Part 1. Diagnostic interventions. Pain Physician 2010; 13:E141-E174.

15. Manchikanti L, Datta S, Gupta S, Munglani R, Bryce DA, Ward SP, Benyamin RM, Sharma ML, Helm II S, Fellows B, Hirsch JA. A critical review of the American Pain Society clinical practice guidelines for interventional techniques: Part 2. Therapeutic interventions. Pain Physician 2010; 13:E215-E264.

16. Manchikanti L, Singh V, Derby R, Helm $S$, Trescot AM, Staats PS, Prager JP, Hirsch JA. Review of occupational medicine practice guidelines for interventional pain management and potential implications. Pain Physician 2008; 11:271-289.

17. Manchikanti L, Singh V, Helm S, Trescot AM, Hirsch JA. A critical appraisal of
2007 American College of Occupational and Environmental Medicine (ACO$E M)$ practice guidelines for interventional pain management: An independent review utilizing AGREE, AMA, IOM, and other criteria. Pain Physician 2008; 11:291-310.

18. Manchikanti L, Singh V, Derby R, Schultz DM, Benyamin RM, Prager JP, Hirsch JA. Reassessment of evidence synthesis of occupational medicine practice guidelines for interventional pain management. Pain Physician 2008; 11:393482.

19. Manchikanti L, Boswell MV, Singh V, Benyamin RM, Fellows B, Abdi S, Buenaventura RM, Conn A, Datta S, Derby R, Falco FJE, Erhart S, Diwan S, Hayek SM, Helm S, Parr AT, Schultz DM, Smith HS, Wolfer LR, Hirsch JA. Comprehensive evidence-based guidelines for interventional techniques in the management of chronic spinal pain. Pain Physician 2009; 12:699-802.

20. Manchikanti L, Singh V, Helm S, Schultz DM, Datta S, Hirsch J. An introduction to an evidence-based approach to interventional techniques in the management of chronic spinal pain. Pain Physician 2009; 12:E1-E33.

21. Manchikanti L. Singh V, Datta S, Cohen SP, Hirsch JA. Comprehensive review of epidemiology, scope, and impact of spinal pain. Pain Physician 2009; 12: E35-E70.

22. Manchikanti L, Boswell MV, Singh V, Derby R, Fellows B, Falco FJE, Datta S, Smith HS, Hirsch JA. Comprehensive review of neurophysiologic basis and diagnostic interventions in managing chronic spinal pain. Pain Physician 2009; 12:E71-E120.

23. Manchikanti L, Boswell MV, Datta S, Fellows B, Abdi S, Singh V, Benyamin RM, Falco FJE, Helm S, Hayek S, Smith HS. Comprehensive review of therapeutic interventions in managing chronic spinal pain. Pain Physician 2009; 12: E123E198.

24. Manchikanti L, Singh V, Pampati V, Boswell MV, Benyamin RM, Hirsch JA. Description of documentation in the management of chronic spinal pain. Pain Physician 2009; 12:E199-E224.

25. Manchikanti L, Helm S, Singh V, Benyamin RM, Datta S, Hayek S, Fellows B, Boswell MV. An algorithmic approach for clinical management of chronic spinal pain. Pain Physician 2009; 12:E225E264.

26. Krames E, Poree LR, Deer T, Levy R. Rethinking algorithms of pain care: the use of the S.A.F.E. principles. Pain Med 2009; 10:1-5. Comment in: Pain Med 2009; 10:944; author reply 945-946. 
